$$
\text { JOES } \begin{aligned}
& \begin{array}{l}
\text { Journal } \\
\text { of Educational } \\
\text { Study }
\end{array}
\end{aligned}
$$

ISSN 2798-0650

Volume 1 Issue 32021

DOI: $10.36663 /$ joes.v1i3.184

\title{
The Implementation of Total Physical Response in English Learning for Attention Deficit Hyperactivity Disorder Students
}

\author{
Kadek Nesya Febi Pramesti, Universitas Pendidikan Ganesha, Indonesia \\ nesyafebipramesti@gmail.com
}

\begin{abstract}
This study aimed to describe the implementation process of Total Physical Responsemethod in teaching English and the response from students with attention deficit hyperactivity disorder. This study used descriptive qualitative as research design with observation and interview. The participants in this study were five students who had attention deficit hyperactivity disorder in one of special need schools in Bali. The result showed that implementing Total Physical Response method made the students easier in remembering new English vocabularies as well as made them felt comfortable and enjoy the teaching and learning process. They were also being motivated and active during the learning process. It could be seen that when students with attention deficit hyperactivity disorder were taught by the Total Physical Response technique which was suitable with their nature as hyperactive students, they could learn well while still doing many actions that they liked and relieved their stress in learning. It meant that the Total Physical Response technique could be the alternative method for teacher to overcome the problem which was faced by students with attention deficit hyperactivity disorder.
\end{abstract}

Keywords: Attention Deficit Hyperactivity Disorder, English language teaching, Total Physical Response method

\section{Introduction}

English is a language that should be learnt because it becomes the most common spoken language worldwide which is used. Sariyati (2013) has mentioned that learning English can be beneficial not only for academical purposes, but also for different relative field, such as for industrial and business purposes which involve a wide range of connection. Nowadays, learning English becomes important because it helps people to communicate with global citizens. English is also important in education and working fields. In education field, English is important because the sources for the learning are mostly written in English. Students are expected to use English well to help them understand the material that is written in English. According to Nishanthi (2018), university students mostly study all their subjects in English in order to make it easier for international students to access the materials. In working fields, English is important because mostly companies need employee who can speak English well. It will help the company to work with people from other countries. In every country, teaching English has different types which it could be as first language, second language, or foreign language. Learning English increases the quality of human resource in a 
ISSN 2798-0650

Volume 1 Issue 32021

DOI: $10.36663 /$ joes.v1i3.184

country. People can compete with other people from all around the world. Increasing the quality of human resource should be started in school by giving English lesson.

Learning English is important because it helps people to communicate easily with global citizens. Teaching English is now already offered in primary and even in pre-school education. According to Lin and Chien (2010), teaching English to students can be divided into 3, namely TESL, TESOL, and TEFL. TESL stands for "Teaching English as a Second Language" is where the English as second language in the country and the learners have wide access in using English besides in the class. Peng (2019) states that in ESL countries, the status of English to their mother tongue is the same or more important. The term of TESOL means "Teaching English to Speakers of Other Language". TESOL is teaching English for speakers who live in a country where English is not their first language. TEFL is abbreviation for "Teaching English as a Foreign Language" where English is a foreign language and the learners do not have wide access in using English besides in the class. Peng (2019) mentions that TEFL means teaching English in a country where English is not mother tongue or second language. Indonesia is included in TEFL country because English is not their mother tongue but a foreign language. Teacher can use various methods in teaching English for TEFL countries. Ratminingsih (2017) mentions that there are some methods that can be used in teaching English for TEFL countries, namely grammar translation method, direct method, suggestopedia, natural approach, audio-lingual, silent way, total physical response, communicative language teaching, and task-based language teaching. It can be concluded that teaching English is important because English as the international language.

Teachers should pay attention in teaching English. In the teaching and learning process, a teacher will meet various types of students. One of them is student with special needs, especially Attention Deficit Hyperactivity Disorder or ADHD students. Sousa (2001) says that ADHD is one of the syndromes that exist, where the syndrome interferes someone's ability to control their focus, activity level, and inhibit behavior. Students with ADHD are struggling to control their focus while doing an activity. For the example, they follow the instructions, however, they try to find another activity as well. Students with ADHD are struggling in controlling their activity level and their hand of grabbing things in front of them which then cause them to interrupt others people and talk in inappropriate times. Moreover,they also cannot stay still and like to move around. Their energy is always full and never feels tired which means that students with ADHD will not focus to finish their task(Copeland \& Love, 1992).

According to Nixon and Richardson (2004), Attention Deficit Hyperactivity Disorder (ADHD) affects 1-3 percent of the world's population. One of the most common learning disorders that affects children and adolescents is Attention Deficit Hyperactivity Disorder (Sousa, 2001). Sousa (2001) stated that attention deficit hyperactivity disorder is a disorder that affects 8 percent to 10 percent of students in this world. Boys are more likely diagnosed with attention deficit hyperactivity disorder three times than girls, although there is not any reason why it can be happened. Attention Deficit Hyperactivity Disorder (ADHD) affects a person's ability to keep attention, executive function (the brain's ability to initiate and manage tasks), and working memory. According to Douglas (2005), Attention Deficit Disorder causes children to act without thinking, to be hyperactive, and to have difficulty in 


\section{J OES $\mid \begin{aligned} & \text { Journal } \\ & \text { of Educational } \\ & \text { Study }\end{aligned}$}

ISSN 2798-0650

Volume 1 Issue 32021

DOI: $10.36663 /$ joes.v1i3.184

focusing which affect their learning process as they struggle to follow instructions because they tend to move around anddo not pay any attention.

There are various types of Attention Deficit Hyperactivity Disorder, namely "inattentive type", "hyperactive-impulsive type", and "combined inattentive \& hyperactivityimpulsive type" (American Psychiatric Association, 2013). Individuals with the inattentive personality find it difficult to plan or complete tasks, pay attention to details, and follow instructions. Individual with hyperactivity-impulsive type is hard to sit still and talk a lot. People with hyperactivity-impulsive type may interrupt others by grabbing things and speak in the wrong time. Individual with a combined two types of ADHD has symptoms from both types. It can be concluded that attention deficit hyperactivity disorder is a syndrome that makes someone cannot focus and stay still in an activity.

According to Douglas (2005), children who have attention deficit hyperactivity disorder act without thinking, are hyperactive, and have trouble focusing. Teachers should give more attention to them because they cannot attend detail and sit still in the class. Teachers need find an appropriate method to teach students with attention deficit hyperactivity disorder. According to Bodnar (2015), Total Physical Response is the most appropriate method for teaching students with syndrome called Attention Deficit Hyperactivity Disorder. There are some reasons why using Total Physical Response, namely; reduces stress level of students with ADHD, allows students to speak if they are ready; and students can say commands to direct their peers. Therefore, Total Physical Response can be effective to teach students with attention deficit hyperactivity disorder.

Total Physical Response is a technique which promoted by James Asher for teaching a target language by giving commands to the students and students will response by doing physical activity. According to Nunan (1991), teachers should give the students an input by giving them to do commands. In TPR method, there is command drill that makes students' vocabulary increase. Richards and Rodgers (2001) mentioned that TPR method is a method that based on coordination between speaking and action. This is an attempt to teach students the language through physical activity. TPR method is a teaching method that combines the target language and gesture to make the learning process more natural and memorable. The learning theory which is developed by Asher believes that learning a language by using motoric activities, which are physical activities improve the meaningful learning (Levey \& Polirstok, 2011). The body movement appears to be an effective mediator for interpreting, organizing, and storing macro-detail of verbal input (Richards \& Rodgers, 1986).

The aim of total physical response is to stimulate the students in using their ways to acquire their mother languages in learning a target language (Mariyam \& Musfiroh, 2019). According to Brown (2007), Total Physical Response (TPR) is linked to the "trace theory," which states that the more physical actions used in learning the target language, the better the remembrance in learners' minds. It is possible to deduce that Total Physical Response is a technique to helps students to learn their target language as the way they learn their mother tongue. Some researchers conducted similar studies which are related to this study. The first study was conducted by Peiman, Masoome, and Leili (2015). This research aimed to investigate the impact of Total Physical Response as the method to improve students ADHD's vocabulary retention. The study was involving 65 experienced English language 
ISSN 2798-0650

Volume 1 Issue 32021

DOI: $10.36663 /$ joes.v1i3.184

teachers of one language institute in Iran. This study applied quantitative research. The data of the study were collected by using questionnaire. The result of this study revealed that using Total Physical Response for improving the vocabulary retention of hyperactivity students impact positively than other methods. The class was enjoyable and active by using Total Physical Response method for children with attention deficit hyperactivity disorder.

Mariyam and Musfiroh (2019) conducted a study about describing the Total Physical Response as a method in English class. The aim of this study was to describe how Total Physical Response as method in improving English vocabulary achievement for five until six years old children. This study was involving 15 students of one kindergarten in Riau. This study applied qualitative research. The data of the study were collected utilizing descriptive statistics. The result of this study was showing that in vocabulary acquisition, noun had highest percentage at $97.78 \%$, then verb at $86.67 \%$, and the last was adjectives at $62.22 \%$. Nuraeni (2019), in her study, described the use of Total Physical Response method for young learners. This study was involving one teacher and thirty students in one of orphanage in Jakarta. This study applied descriptive qualitative research. The data collection was done by doing observation and the instruments that used were pre-test and post-test. The result revealed that using Total Physical Response increased students' ability in learning English, especially vocabulary. The Total Physical Response made students felt confident to explore their ability in the target language. The Total Physical Response method for learning also encouraged students' self-confident, curiosity, creativity, and motivation. It helped the learning process in the class more flexible and fun.

Since the attention deficit hyperactivity disorder or ADHD is a syndrome which make the students fail to focus in learning and tend to do unnecessary physical activities, this study aim to assist the teacher to find an alternative method to overcome the issue where the students with ADHD can learn well while doing physical activities because they have a disorder which interferes their focus in learning. By looking at those prior researches, the Total Physical Response or TPR technique can be an alternative method because the technique can provide them physical activities while learning English enjoyably and even advance their ability. It means that they do not have to struggle with their nature of ADHD like sitting in one place and just stand still until the learning process is over, but they can move like what they love while learning English because TPR technique is flexible to be implemented.

\section{Method}

The method used in this study was descriptive qualitative. Descriptive qualitative method in this study used to explain the implementation and the results of implementing Total Physical Response in English learning process for ADHD students in one of schools for students with special needs in Denpasar. The participants of this study were five students with attention deficit hyperactivity disorder. In data collection, the researcher used two instruments in this study namely observation and interview. The observation and interviews were done with English teacher and students with attention deficit hyperactivity disorder. The observation was carried out to find out how the teaching and learning process through Total Physical Response method for students with attention deficit hyperactivity disorder. The interview was carried out to find out the responses from English teacher and students with 


\section{JOES $\begin{aligned} & \begin{array}{l}\text { Journal } \\ \text { of Educational } \\ \text { Study }\end{array} \\ & \text { Jtudion }\end{aligned}$}

ISSN 2798-0650

Volume 1 Issue 32021

DOI: $10.36663 /$ joes.v1i3.184

attention deficit hyperactivity disorder after the teaching and learning process using TPR method. The steps of data analysis were observing, exploring and presenting the results.

\section{Findings and Discussion}

The Process of Implementation Total Physical Response (TPR) Method in Teaching and Learning Activity for ADHD students

This study concerns about the implementation of Total Physical Response method in teaching English for students with ADHD. The researcher explores the activities of teaching and learning process with TPR method. Total Physical method is an appropriate and interesting method for students who have attention deficit hyperactivity disorder. The researcher describes the implementation of TPR method in teaching and learning process into four aspects, namely learning aims, implementation, teacher's roles, and students' roles.

1. The aim of teaching English using Total Physical Response method to students with ADHD

The aims in using Total Physical Response method for students with attention deficit hyperactivity disorder are helping the students to understand and memorize the words or vocabulary in learning English, and creating the fun and interesting learning process for students who have ADHD. The teacher gives new word or vocabulary to the students through giving instruction then it will be followed by the students. TPR method creates the teaching and learning English is fun and helps students to remember the vocabulary.

2. The implementation of TPR method in teaching English to students with ADHD

There are three activities in teaching and learning process, namely opening activity, main activity, and closing activity. In the opening activity, the researcher greeted the students by saying "good morning and how are you today?" accompanied by physical movements. So, the students would follow the body movements of the researcher. Then the researcher asked the students about their favorite animals. The animals are the material that will be taught to the students.

In the main activity, the researcher began with showing pictures of animals, such as chicken, dog, lion, pig, monkey, snake, cow, sheep, goat, eagle, turtle, squirrel, duck, gorilla, elephant, and cheetah. The researcher said the name of animals first then followed by the students. After all pictures were already showed, the teacher gave a video with a song. The video consisted with the name of animals and the body movements of the animals. The name of the song was animals in action and it can be searched on YouTube. The researcher sang the song and asked the students to follow the researcher's body movements or from the video.The researcher and students sang the song and demonstrated animals' movement together. The song and body movements were repeated until the students remember the movement of each animal. 


\section{J OES $\mid \begin{aligned} & \text { Journal } \\ & \text { of Educational } \\ & \text { Study }\end{aligned}$}

ISSN 2798-0650

Volume 1 Issue 32021

DOI: $10.36663 /$ joes.v1i3.184

After singing the song, the researcher asked students how to demonstrate the name of animal she was saying. For example,"What is the movement of monkey?" then the students would jump together. The researcher also prepared the guessing games. The students should guess the name of animals that their friend was demonstrating. Four students lined up and one student demonstrated the animal's movements. The researcher stood up behind the four students and showed the picture of animal to one student that would demonstrate it. The game was done until all pictures were answered correctly. From these activities the students with ADHD could learn English and focus to remember the word because the teaching and learning activitywas done by physical movements. In the closing activity, the researcher invited the students to sing once more and mentioned the name of animals that had been studied before closing the teaching and learning process. The researcher closed the teaching and learning process by saying "Thank you and good bye" and the students responded it.

3. The teacher's role in the class

Teacher has many roles in teaching and learning process. According to Harmer(2007)stated that teacher has many roles such as controller, prompter, tutor, model, and organizer. In teaching and learning process, the researcher found the roles of teacher. The role teacher as a controller, it can be shown when the teacher manages the teaching and learning activity from opening to closing activity. The role of teacher as prompter is when directing the students in the teaching and learning activity and also gives material to the students. The role of teacher as an organizer, it is shown when the teacher has responsibility to organize the students in the class, make instructions, and get feedback from the students. This activity is accordance with the concept of Total Physical Response method. The teacher role as tutor is helping the students when having difficulties in teaching and learning process. The other role of teacher is model, teacher becomes a model for the students by demonstrate the body movements in front of the class.

4. The students' role in the class

From the result of observation in the class, the researcher found the students' role in teaching and learning activity using Total Physical Response method, namely member, listener, and performer. The role of students as member in the teaching and learning process are being active in the class and following the instructions given from the teacher. The other role of students is as listener. The students as listener are listening to teacher explanation and instructions in the teaching and learning activity. The last role of students is as performer. Students as performer in the class are getting the instructions by the teacher and then demonstrating in the class.

\section{Students' Response after Teaching and Learning Process through TPR Method}

The interview with attention deficit hyperactivity disorder students is carried out to find other information in this study. The other aim of interview in this study is to find specific answer from the students with attention deficit hyperactivity disorder. The question in this 


\section{JOES $\begin{aligned} & \begin{array}{l}\text { Journal } \\ \text { of Educational } \\ \text { Study }\end{array} \\ & \text { Studion }\end{aligned}$}

ISSN 2798-0650

Volume 1 Issue 32021

DOI: $10.36663 /$ joes.v1i3.184

interview is delivered to 5 students with ADHD and the question is "Why are you interested using Total Physical Response method in learning English?" The result of this interview can be seen in Table 1

Table 1. The result of interview with ADHD students

\begin{tabular}{|c|c|c|c|}
\hline $\begin{array}{l}\text { Number of } \\
\text { Student }\end{array}$ & No. & Teacher (Interviewer) & Student (Interviewee) \\
\hline \multirow{3}{*}{ Student 1} & 1. & $\begin{array}{l}\text { "Do you like to be taught by TPR } \\
\text { method like the previous meeting? }\end{array}$ & "Yes, I do, Ms." \\
\hline & 2. & $\begin{array}{l}\text { "Why do you like to be taught by } \\
\text { TPR method?" }\end{array}$ & $\begin{array}{l}\text { "It is because I can enjoy the English } \\
\text { learning, Ms. I also do not afraid to talk } \\
\text { in English." }\end{array}$ \\
\hline & 3. & $\begin{array}{l}\text { "Well, you become more confident to } \\
\text { learn English, right?" }\end{array}$ & "Yes, I am, Ms." \\
\hline \multirow{3}{*}{ Student 2} & 1. & $\begin{array}{l}\text { "Do you like to be taught by TPR } \\
\text { method like the previous meeting? }\end{array}$ & "Yes, I do, Ms." \\
\hline & 2. & $\begin{array}{l}\text { "Why do you like to be taught by } \\
\text { TPR method?" }\end{array}$ & $\begin{array}{l}\text { "It is because I like to learn through } \\
\text { activities, Ms. So, I can enjoy the } \\
\text { process of learning and the lesson } \\
\text { becomes more enjoyable." }\end{array}$ \\
\hline & 3. & $\begin{array}{l}\text { "It means learning English through } \\
\text { activities become more enjoyable, } \\
\text { right?" }\end{array}$ & "Yes, that is right, Ms." \\
\hline \multirow{3}{*}{ Student 3} & 1. & $\begin{array}{l}\text { "Do you like to be taught by TPR } \\
\text { method like the previous meeting? }\end{array}$ & "Yes, I do, Ms." \\
\hline & 2. & $\begin{array}{l}\text { "Why do you like to be taught by } \\
\text { TPR method?" }\end{array}$ & $\begin{array}{l}\text { "It is because being taught by TPR } \\
\text { method makes the learning process } \\
\text { interesting, Ms. I can enjoy the English } \\
\text { learning process with exciting } \\
\text { activities." }\end{array}$ \\
\hline & 3. & $\begin{array}{l}\text { "It means being taught by TPR } \\
\text { method as our previous meeting } \\
\text { makes you not bored during the } \\
\text { lesson, right? }\end{array}$ & "Yes, Ms. I do not feel bored." \\
\hline \multirow{3}{*}{ Student 4} & 1. & $\begin{array}{l}\text { "Do you like to be taught by TPR } \\
\text { method like the previous meeting? }\end{array}$ & "Yes, I do, Ms." \\
\hline & 2. & $\begin{array}{l}\text { "Why do you like to be taught by } \\
\text { TPR method?" }\end{array}$ & $\begin{array}{l}\text { "It is because the English learning } \\
\text { process becomes more enjoyable, Ms. I } \\
\text { can remember the name of animals } \\
\text { faster in English. The learning } \\
\text { activities of imitating animals gesture } \\
\text { make me happy, Ms." }\end{array}$ \\
\hline & 3. & $\begin{array}{l}\text { "It means you like the TPR method } \\
\text { because it is enjoyable and help you } \\
\text { to remember the English } \\
\text { vocabularies, right?" }\end{array}$ & $\begin{array}{l}\text { "Yes, Ms. It makes me love learning } \\
\text { English." }\end{array}$ \\
\hline \multirow{2}{*}{ Student 5} & 1. & $\begin{array}{l}\text { "Do you like to be taught by TPR } \\
\text { method like the previous meeting? }\end{array}$ & "Yes, I do, Ms." \\
\hline & 2. & $\begin{array}{l}\text { "Why do you like to be taught by } \\
\text { TPR method?" }\end{array}$ & $\begin{array}{l}\text { "It is because learning through TPR } \\
\text { method makes me happy, Ms. I can }\end{array}$ \\
\hline
\end{tabular}


J O ES $\begin{aligned} & \begin{array}{l}\text { Journal } \\ \text { of Educational } \\ \text { Study }\end{array} \\ & \text { Studion }\end{aligned}$

ISSN 2798-0650

Volume 1 Issue 32021

DOI: $10.36663 /$ joes.v1i3.184

\begin{tabular}{|l|l|l|l|}
\hline & & $\begin{array}{l}\text { learn English without any boredom. I } \\
\text { also can move and not only sit during } \\
\text { the lesson." }\end{array}$ \\
\cline { 2 - 5 } & 3. & $\begin{array}{l}\text { "It means the TPR method makes } \\
\text { you happy in learning English, right? }\end{array}$ & "Yes, that is right, Ms." \\
\hline
\end{tabular}

As shown on the Table 1 above, there were 5 interviews which were recorded from the students with attention deficit hyperactivity disorder or ADHD. Those students were asked in interview after they were treated with the Total Physical Response or TPR technique during English learning. Each student was asked with similar question which was used to find out their response toward the technique that had been treated to them.

Based on the interview above, it can be seen that were positively response the TPR that they received during the English learning. The first student (S1) stated that the TPR technique made the learning process became enjoyable and washed away S1's fear in learning English. This is in line with the result of previous study that had been conducted by Nuraeni (2019), which stated that the TPR technique could be beneficial to promote students' self-confidence in learning. From the answer of second question from S1, it could be seen that fear was the problem which was faced. The S1 could overcome the problem because the TPR technique could provide them with excitement and enjoyable learning process through physical activities which was also in line with their nature as student with ADHD. This is in line with Richards and Rodgers (2001) and Suryaningrum (2018) who stated that the TPR technique involved physical activities as the main attempt through coordination between speaking and action. It means that when students were taught through the technique which matched with their nature, they could learn well and decreased their fear or anxiety. In this case, answer from S1 showed that the TPR technique was suitable for students like S1 because with the TPR technique, S1 could enjoy the lesson and really like it which showed positive result.

Similar response was shown by the second student (S2). S2 liked the TPR technique because the learning process became enjoyable. From the answer of second question, it could be altered that before the $\mathrm{S} 2$ was treated by the TPR technique, the learning process tended to be boring and did not take much attention of S2. It was because S2 was the other ADHD student who would be excited and preferred to do many actions or physical activities. This is in line with Douglas (2005) who stated that students with ADHD could not sit still in a class and tended to do many actions as they were hyperactive. When the S2 was treated by the TPR technique, the learning process became enjoyable and could catch S2's attention which was also in line with the aforementioned statement from S1. Previous study which was conducted by Peiman, Masoome, and Leili (2015) and Savic (2014) also argued similar point. Their study showed that the TPR technique worked well on the students with ADHD because the typical characteristic of TPR matched with their nature as hyperactive students. That was why the learning process became more active, enjoyable, and meaningful for them.

Other students (S3, S4, and S5) also stated the same points. The TPR technique could gave them beneficial impact as a student with ADHD. S2 argued on its second answer that the TPR technique could make the learning process became more exciting through the activities, S3 stated that the TPR technique made the lesson became enjoyable and made S3 memorized the material faster, and S5 implied that the TPR was suitable because it could 


$$
\text { J O ES } \begin{aligned}
& \begin{array}{l}
\text { Journal } \\
\text { of Educational } \\
\text { Study }
\end{array} \\
& \text { oud }
\end{aligned}
$$

ISSN 2798-0650

Volume 1 Issue 32021

DOI: $10.36663 /$ joes.v1i3.184

wash away the boredom through the activities that they liked. From those answers, it could be inferred that the TPR technique was suitable for them because they could do many actions as it was their nature. Their excitement came from the activities which dragged them out from the boredom that commonly caged them to follow the general learning process. This is in line with Bodnar (2015) and Savic (2014) who stated that physical activities which were provided by the TPR technique could relieve the stress of students with ADHD. It means that they should be taught by using the method that was suitable their nature as hyperactive students. The actions that were conducted through the TPR technique could be the medium for them to do what they liked while learning the material and paid more attention on it which meant that the could learn more effectively than without the TPR technique (Peiman, Masoome, \& Leili, 2015; Douglas, 2005;Savic, 2014)

Through those points that were gotten from the interview, it could be seen that the TPR technique which was treated to the students with ADHD gave positive impacts. Excitement, enjoyment, self-confidence, no boredom, and learn faster became the points that highlighted the positive result which were brought by the TPR technique toward the students with ADHD. From this point, it could be seen that the students with ADHD could overcome their nature as hyperactive students that generally interfered their learning process by implementing a method which could be the medium for them to be what they actually were. The TPR technique could provide them with the actions and many physical activities which naturally could facilitate their habit. It meant that the TPR technique could be an alternative for teacher to overcome the issue which was brought by the students with ADHD.

\section{Conclusion and Suggestion}

The implementation of Total Physical Response method in teaching and learning process encourages students' motivation, creativity, and self-confident. It also makes students enjoy and being happy while the learning in the class. TPR method makes the teaching and learning process become flexible and fun. This method also can be the alternative technique to overcome the problem which is faced by the students with ADHD. Utilization of TPR method is not difficult to be implemented in the class. Teacher can use song with video in the class to teach the students with ADHD. Nowadays, teacher can find many English songs with body movements in the platform named YouTube. It can help teacher to implement the TPR method to students with ADHD who cannot stay still in the class.

\section{References}

American Psychiatric Association. (2013). Diagnostic and statistical manual of mental disorders (5th ed.). American Psychiatric Association.

Bodnar, M. (2015). Teaching english to young learners with ADHD and dyslexia. World Scientific News, 8, 37-53. https://doi.org/http://www.worldscientificnews.com/wpcontent/uploads/2015/06/WSN-8-2015-37-53.pdf

Brown, D. (2007). Teaching by Principles: An Interactive Approach to language pedagogy (3rd ed.). Pearson Education ESL.

Copeland, E., \& Love, V. L. (1992). Attention without tension. Childhood, Inc.

Douglas, W. (2005). ADHD description. http://www.kidshealth.org/ 


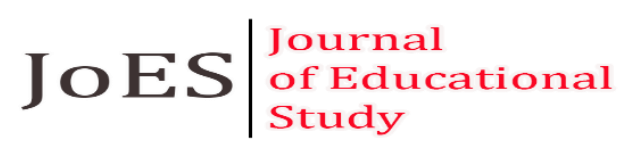

ISSN 2798-0650

Volume 1 Issue 32021

DOI: $10.36663 /$ joes.v1i3.184

parent/medical/learning/behavior/adhd.html

Harmer, J. (2007). The practice of english language teaching. Longman.

Levey, S. K., \& Polirstok, S. S. (2011). Language development: Understanding language diversity in the classroom. SAGE Publications.

Lin, G. H., \& Chien, P. S. (2010). An introduction to english teaching: A textboook for english educators. Saarbrücken.

Mariyam, S. N., \& Musfiroh, T. (2019). Total physical response (TPR) method in improving english vocabulary acquisition of 5-6 years old children. TADRIS: Jurnal Keguruan Dan Ilmu Tarbiyah, 4(2), 257-264. https://doi.org/10.24042/tadris.v4i2.4071

Nishanthi, R. (2018). The importance of learning english in today world. International Journal of Trend in Scientific Research and Development, 3(1), 871-874.

Nixon, G., \& Richardson, R. (2004). Attention Deficit Hyperactivity Disorder (ADHD).A Practical Guide for Schools. South Eastern Education and Library Board.

Nunan, D. (1991). Language teaching methodology. Cambridge University Press.

Nuraeni, C. (2019). Using total physical response (TPR) method on young learners english language teaching. METATHESIS: Journal of English Language Literature and Teaching, 3(1), 26-34. https://doi.org/10.31002/metathesis.

Peiman, R., Masoome, N., \& Leili, D. (2015). Enhancing vocabulary retention of children with ADHD via total physical response. International Coference on 21 st Century Education, 7(1), 175-184.

Peng, S. (2019). A study of the differences between EFL and ESL for english classroom teaching in china. IRA- International Journal of Education \& Multidisciplinary Studies, 15(01), 32-35. https://doi.org/http://dx.doi.org/10.21013/jems.v15.n1.p4

Ratminingsih, N. M. (2017). Metode dan strategi pembelajaran bahasa Inggris. PT. Raja Grafindo Persada.

Richard, J. C., \& Rodgers, T. S. (2001). Approches and methods in language teaching. Cambridge University Press.

Richards, J. C., \& Rodgers, T. S. (1986). Approaches and methods in language teaching: A description and analysis. Cambridge University Press.

Sariyati, I. (2013). The Effectiveness of TPR (Total Physical Response) Method in English Vocabulary Mastery of Elementary School Children. PAROLE: Journal of Linguistics and Education, 3(1 April), 50-64-64. https://doi.org/10.14710/parole.v3i1April.4458

Savic, V. M. (2014). Total Physical Response ( Tpr ) Activities in Teaching English To Young Learners. Физичка Култура И Модерно Друштво, Пос. Изд, Кю., 17(September), 447-454.

Sousa, D. A. (2001). How the special needs brain learns. Corwin Press.

Suryaningrum, D. (2018). The Effect of Total Physical Response Technique on the Eleventh Graders' Speaking Ability at SMA PSKD 7 Depok. JET (Journal of English Teaching), 3(1), 55. https://doi.org/10.33541/jet.v3i1.699 